BISMA

(Bisnis dan Manajemen)

\title{
Analisis Usaha Industri Rumahan Emping Melinjo Di Desa Cilowong dengan Menggunakan Pendekatan Rasio dan Profitabilitas
}

\author{
Lorherson Debataraja
}

STIE Banten

Email korespondensi: helmutbunu@yahoo.co.id

\begin{abstract}
The purpose of this research is to know the amount of cost, acceptance, profit, profitability, and business risk emping melinjo household scale in Cilowong Village, Taktakan sub-district, Serang city, Banten. Determination of sample area is done by purposive that is Kampung Cilowong. Sampling of respondents is done by proportional. Its population is all businessmen emping melinjo household scale in Cilowong Village. The number of respondents as many as 40 people. The data used are primary data and secondary data. Technique of collecting data is done by observation, interview, and recording. Data analysis using ratio and profitability approach. Based on the results of the study it can be concluded that: 1) Average total cost incurred of Rp40.085.250,00; 2) emping

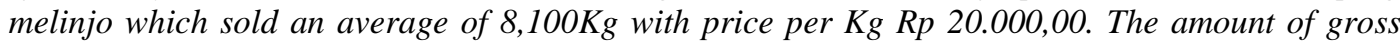
receipts is Rp51.300.000,00. The profit earned an average of Rp11,214,750.00 with an average of 9 employees; 3) Profitability of 21.86\%; and 4) industrial efficiency of 0.27.
\end{abstract}

Keywords : Home Industry;Emping Melinjo;Profitability

Received: 6 September 2017 Reviewed: 10 Oktober 2017 Accepted: 30 Oktober 2017 Published: 31 Oktober 2017

\section{PENDAHULUAN}

Emping melinjo adalah sejenis keripik yang dibuat dari biji melinjo yang telah tua. Proses pembuatan emping tidak sulit dan dapat dilakukan dengan menggunakan alat-alat sederhana. Emping melinjo merupakan salah satu komoditi pengolahan hasil pertanian yang memiliki nilai tinggi, baik karena harga jual yang relatif tinggi maupun sebagai komoditi ekspor yang dapat mendatangkan devisa. Sejauh ini, emping diekspor ke negara-negara tetangga di antaranya ke Singapura, Malaysia dan Brunei. Bahkan, pasar ekspor yang potensial menjangkau Jepang, Eropa dan Amerika.

Di sekitar kita ini banyak tumbuhan penghasil makanan yang berasal dari biji, daun, batang, buah dan akar. Melinjo salah satu penghasil makanan yang diambil dari buahnya. Buah melinjo yang sudah tua banyak mengandung zat-zat 
karbohidrat yang sangat berguna untuk dikonsumsi. Biji mlinjo di samping sebagai pengganti lauk pauk bagi penduduk, dapat juga dibuat berbagai macam makanan ringan. Daun dan batangnya juga dapat digunakan sehingga pohon melinjo ini ditanam di kebun warga masyarakat. Batangnya dapat digunakan sebagai kayu bakar. Sedangkan daunnya dapat digunakan sebagai tambahan sayuran buat lauk pauk. Pohon melinjo dapat hidup subur di kebun, pekarangan maupun tegalan. Pohon melinjo mempunyai nilai ekonomi sangat rendah sehingga perlu adanya pemanfaatan nilai jual melinjo.

Tanaman melinjo dapat tumbuh pada ketinggian tempat 0-1.200 m dpl. Dengan demikian, tanaman melinjo dapat tumbuh di pegunungan berhawa lembab, bisa juga didataran rendah yang relatif kering. Agar dapat berproduksi secara maksimal, pohon melinjo sebaiknya ditanam di dataran rendah yang ketinggiannya tidak lebih dari $400 \mathrm{~m}$ dpl dan dengan curah hujan sekitar 3.000$5.000 \mathrm{~mm} /$ tahun merata sepanjang tahun.

Pohon melinjo sudah dapat dipanen setelah berumur 5-6 tahun. Panen dilakukan dua kali setahun. Panen besar sekitar bulan Mei-Juli, sedangkan panen kecil sekitar bulan Oktober-Desember. Sedangkan pemungutan bunga dan daun muda dapat dilakukan kapan saja. Hasil melinjo per pohon untuk tanaman melinjo yang sudah dewasa bervariasi antara 15.000-20.000 biji.

Salah satu usaha untuk menaikkan harga melinjo adalah dengan membuat emping melinjo. Emping melinjo adalah sejenis keripik yang dibuat dari biji melinjo yang telah tua. Proses pembuatan emping tidak sulit dan dapat dilakukan dengan menggunakan alat-alat sederhana. Emping melinjo merupakan salah satu komoditi pengolahan hasil pertanian yang memiliki nilai tinggi, baik karena harga jual yang relatif tinggi maupun sebagai komoditi ekspor yang dapat mendatangkan devisa. Sejauh ini, emping diekspor ke negara-negara tetangga di antaranya ke Singapura, Malaysia dan Brunei. Bahkan, pasar ekspor yang potensial menjangkau Jepang, Eropa dan Amerika.

Cara pembuatannya mudah dan tahan lama, serta bahan bakunya mudah didapat dan alat-alat yang digunakan sederhana dan setiap rumah tangga pasti mempunyai alat tersebut. Salah satu bentuk industri kecil yang berkembang di Indonesia adalah di bidang pangan. Menurut Kemenperin (2017), keberadaan industri pangan di Indonesia dapat menyerap tenaga kerja dalam jumlah yang cukup banyak serta mampu mendorong berdirinya industri penunjang seperti industri pengolahan makanan dan industri kemasan yaitu suatu industri yang memproduksi kemasan suatu produk seperti kemasan berbahan baku plastik, kertas, kaca, dan lainnya.

Pertama-tama yang harus dilakukan adalah memutus hambatan psikologis dari masyarakat. Kalau sebagian masyarakat anti emping karena menderita sakit asam urat, bukan berarti penanaman melinjo harus dilarang dan industri emping berhenti. Kedua, pengembangan areal malinjo secara besar-besaran layak untuk 
dilakukan oleh Pemkab dan Pemprov. Para penangkar benih di lapangan, siap dengan melinjo unggul dalam jumlah jutaan batang per tahun.

Agroindustri emping adalah bisnis yang sangat-sangat padat karya. Mulai dari panen, pengupasan kulit buah, proses pembuatan emping, pemasakan (oven) dan pengemasan, semuanya memerlukan tenaga kerja dalam jumlah yang sangat banyak. Agroindustri ini juga memerlukan modal besar. Namun nilai investasi tersebut relatif kecil jika dibanding dengan jumlah tenaga kerja yang bakal bisa diserap olehnya. Melinjo adalah komoditas yang sangat strategis bukan hanya untuk menghidupkan perekonomian rakyat, melainkan juga untuk prestise bangsa.

\section{Industri Rumah Tangga}

Menurut Arifia (2017), usaha industri atau industri rumah tangga adalah usaha yang tidak berbentuk badan hukum dan dilaksanakan oleh seseorang atau beberapa orang anggota rumah tangga yang mempunyai tenaga kerja sebanyak empat orang atau kurang, dengan kegiatan mengubah bahan dasar menjadi barang jadi atau setengah jadi atau dari yang kurang nilainya menjadi yang lebih tinggi nilainya dengan tujuan untuk dijual atau ditukar dengan barang lain dan ada satu orang anggota keluarga yang menanggung risiko.

Menurut Menurut Kemenperin (2017), industri dapat digolongkan berdasarkan jumlah tenaga kerja, jumlah investasi dan jenis komoditi yang dihasilkan. Berdasarkan jumlah tenaga kerja, industri dapat dikategorikan menjadi empat kelompok, yaitu: (1) jumlah tenaga kerja 1-4 orang untuk industri rumah tangga, (2) jumlah tenaga kerja 5-19 orang untuk industri kecil, (3) jumlah tenaga kerja 20-99 orang untuk industri menengah, dan 4) jumlah tenega kerja lebih atau sama dengan 100 orang untuk industri besar

Industri kecil dan rumah tangga terdapat pola subsisten yang tercermin dalam tingginya peran relatif dari penggunaan pekerja keluarga (unpaid family worker), yakni mendekati 95,5\% dari keseluruhan tenaga kerja yang ada dari industri kecil dan rumah tangga yang bersangkutan.

Wahyuni dan Nurhadi (2013: 1-20 menjelaskan bahwa faktor-faktor produksi yang terkait dengan industri emping melinjo meliputi modal: jumlah modal awal, asal modal,bantuan pemerintah dalam modal, kepemilikan sertifikat usaha, bahan baku: cara memperoleh bahan baku, asal bahan baku, frekuensi penggunaan bahan baku, sistem pengolahan bahan baku, biaya bahan baku, tenaga kerja: jumlah tenaga kerja, asal tenaga kerja, tingkat pendidikan tenaga kerja, usia tenaga kerja, sistem pembayaran upah, pemasaran: cara pemasaran, wilayah pemasaran, intensitas penjualan pemasaran, frekuensi hasil produk, kepemilikan etalase, transportasi: alat transportasi, kepemilikan alat transportasi, dan sumber energi: jenis sumber energi;

Peluang pengembangan industri kecil dan rumah tangga di bidang pangan di Indonesia terbuka sangat luas, hal ini dimungkinkan karena adanya dukungan 
faktor internal yang kuat. Faktor internal yang memperkuat pengembangan industri pangan adalah: (1) besarnya jumlah penduduk yang menjadi pasar produk industry; (2) tingkat pendapatan masyarakat yang semakin meningkat yang mendorong permintaan akan produk pangan olahan. Hal ini dapat menunjukkan bahwa pengeluaran rata-rata perkapita sebulan akan produk pangan dan minuman olahan meningkat; (3) cukup tersedianya sebagian besar bahan baku produksi di dalam negeri; (4) cukup tersedianya tenaga kerja dengan upah yang relatif rendah; dan (5) kapasitas produksi beberapa usaha industri pangan yang masih dapat ditingkatkan (Asri, 2010:25).

Wahyuni dan Nurhadi (2013: 1-20) menjelaskan bahwa terdapat 13 strategi pengembangan yang tepat dilakukan guna pengembangan usaha industri emping melinjo, yaitu: (1) peningkatan pengembangan inovasi produk emping melinjo, (2) pengembangan jaringan yang lebih luas, (3) adanya penyuluhan inovasi produk agar lebih berkembang, (4) meningkatkan kualitas produk yang dihasilkan, (5) pemerintah memberikan penyuluhan mengenai tips aman setelah mengkonsumsi emping melinjo, (6) melakukan produksi dalam skala besar apabila musim panen tiba, (7) pemerintah mengadakan pertemuan intensif bersama para pengrajin dan mengadakan pelatihan di wilayah sentra industri emping melinjo, (8) memanfaatkan bantuan dari pemerintah, (9) meningkatkan promosi baik media cetak maupun media elektronik, (10) pemerataan pembagian bantuan modal, (11) adanya showroom yang khusus menjual hasil produk baik di tingkat kecamatan maupun Kabupaten, (12) meningkatkan pelayanan, dan (13) pembinaan yang intensif mengenai teknologi tepat guna.

Biaya adalah nilai dari semua masukan ekonomik yang diperlukan, yang dapat diperkirakan dan dapat diukur untuk menghasilkan sesuatu produk (Iqbal, 2017). Menurut Dryana (2017), biaya tetap adalah biaya produksi yang timbul karena penggunaan faktor produksi yang tetap, sehingga biaya yang dikeluarkan untuk membiayai faktor produksi tetap itu juga tetap tidak berubah walaupun jumlah barang yang dihasilkan berubah-ubah. Biaya variabel adalah biaya yang dikeluarkan oleh pengusaha sebagai akibat penggunaan faktor produksi variabel, sehingga biaya ini besarnya berubah-ubah dengan berubahnya jumlah barang yang dihasilkan. Biaya total menurut Samuelson dan Nordhaus (2003) berarti total pengeluaran terendah yang diperlukan untuk memproduksi setiap tingkat output. Sedangkan menurut Devvy (2017), total biaya (TC = Total Cost) adalah jumlah total biaya tetap dan biaya variabel. $\mathrm{TC}=\mathrm{TFC}+\mathrm{TVC}$.

Biaya-biaya atas penggunaan harta atau aktiva milik perusahaan seperti bangunan, alat dan mesin, terdiri dari biaya uang yang terikat pada harta itu dan pembebanannya disebut penyusutan, yang dianggap sebagai hilangnya nilai harta itu karena digunakan dalam proses produksi. Para akuntan menggunakan beberapa metode konvensional, mengenai penyusutan yang didasarkan atas harga perolehan yang dibayarkan untuk harta itu. Salah satu metode yang digunakan dalam 
penyusutan adalah metode garis lurus, dimana besaran yang sama dari biaya historis dikurangkan setiap tahunnya, selama umur penggunaan harta itu.

\section{METODE PENELITIAN}

Penentuan daerah sampel dilakukan secara sengaja (purposive) yaitu Kampung Cilowong. Pengambilan sampel responden dilakukan dengan cara proporsional. Populasinya adalah seluruh pengusaha emping melinjo skala rumah tangga di Desa Cilowong. Adapun jumlah responden sebanyak 40 orang. Data yang digunakan adalah data primer dan data sekunder. Teknik pengumpulan data dilakukan dengan observasi, wawancara, dan pencatatan. Analisis data dengan menggunakan pendekatan rasio dan profitabilitas.

\section{HASIL DAN PEMBAHASAN}

Di Kecamatan Taktakan, Provinsi Banten merupakan satu di antara sentra industri emping melinjo yang relatif besar di Indonesia. Sentra tersebut tersebar tidak hanya di Kecamatan Taktakan, tetapi hampir di seluruh kabupaten di Banten. Usaha emping melinjo di Kabupaten Taktakan sudah dirintis sejak tahun 1960-an. Sebelumnya, biji melinjo yang dihasilkan di daerah ini masih belum dimanfaatkan. Data Dinas Perkebunan Banten, hingga akhir tahun 2016, secara keseluruhan luas lahan melinjo di Propinsi Banten sekitar 6.610 ha dengan produksi 14.011 ton buah melinjo. Dari total luas lahan tersebut. Pada awal-awal produksinya, hasil produksi emping melinjo dari Banten tidak hanya dipasarkan di daerah setempat, melainkan juga dipasarkan di Jakarta.

Potensi bahan baku biji melinjo yang banyak tersebut, menempatkan Banten sebagai sentra industri emping yang penting. Data dari Dinas Perindustrian, Perdagangan dan Pasar, Dinas Pertanian dan Peternakan dan Kantor Koperasi menginfomasikan di wilayah Taktakan terdapat 225 pengusaha.

Usaha emping melinjo dijalankan dengan keterlibatan tenaga kerja yang intensif sebagai pengrajin. Pada umumnya, pengusaha emping melinjo membeli peralatan dan bahan baku (biji melinjo) kepada pengrajin untuk digunakan membuat emping. Emping yang dihasilkan oleh pengrajin kemudian jual. Sedangkan tenaga kerja pengrajin akan memperoleh upah dari pengusaha berdasarkan jumlah emping yang dihasilkan.

Kemampuan produksi rata-rata setiap perajin dalam sehari kerja adalah sebesar $10 \mathrm{~kg}$ sampai $12 \mathrm{~kg}$ emping. Adapun harga jual emping adalah Rp20.000,00, namun pada hari hari tertentu seperti hari raya dan tahun baru, harga emping dapat meningkat hingga mencapai Rp50.000,00.

Pembuatan emping menggunakan bahan baku buah melinjo tua, adapun kebutuhan bahan baku setiap pekerja adalah $10 \mathrm{~kg}$ sampai $12 \mathrm{~kg}$ buah melinjo tua. Bahan baku diperoleh dari tanaman di halaman rumah/kebun milik sendiri maupun di beli dari hasil kebun melinjo masyarakat sekitar. 
Untuk mendapatkan bahan baku yang bermutu untuk dapat menghasilkan emping yang baik, maka perlu diperhatikan cara memetik buah melinjo, adapun langkah pengambilan buah melinjo dari pohonnya adalah sebagai berikut: 1) Buah melinjo biasanya dikumpulkan dengan cara dipetik dari atas pohon atau dari buah melinjo yang jatuh dibawah pohon. 2) Buah melinjo yang diambil merupakan buah yang telah benar-benar masak, biasanya berwarna merah ataupun kuning. 3) Jangan ambil buah melinjo yang telah busuk karena akan merusak kualitas emping yang dihasilkan. 4) Kupas buah melinjo dari kulitnya yang lunak sehingga hanya tinggal bijinya. Buah melinjo yang didapat dari bawah pohon (sudah jatuh) dapat langsung dikupas, namun untuk buah melinjo yang baru dipetik dari atas pohon, diamkan selama 2 jam sebelum dikupas, karena getah masih menempel di buah melinjo. 5) Simpan biji melinjo yang telah dikupas selama 1 hari sebelum melakukan langkah selanjutnya.

\section{Analisis Biaya}

Biaya adalah nilai korbanan yang dikeluarkan dalam proses produksi. Biaya dalam penelitian ini adalah seluruh biaya yang dikeluarkan untuk proses pembuatan emping melinjo di Desa Cilowong Kec Taktakan, baik biaya yang benar-benar dikeluarkan atau tidak benar-benar dikeluarkan. Biaya tersebut terdiri dari biaya tetap dan biaya variabel.

Biaya tetap adalah biaya yang digunakan dalam industri emping melinjo yang besarnya tidak dipengaruhi oleh jumlah produk emping melinjo yang dihasilkan. Biaya tetap dalam industri emping melinjo Desa Cilowong Kec Taktakan meliputi biaya penyusutan peralatan dan bunga modal investasi. Biaya penyusutan peralatan dan biaya bunga investasi sebenarnya tidak benarbenar dikeluarkan oleh pengusaha emping melinjo, tetapi karena dalam penelitian ini menggunakan konsep keuntungan, maka biaya ini harus diperhitungkan.

Sumber biaya tetap industri emping melinjo terbesar berasal dari biaya penyusutan peralatan yaitu sebesar 4\%/tahun, karena diperkirakan peralatan tersebut dapat digunakan rata-rata selama 25 tahun (bahkan lebih). Secara rupiah. perbedaan jumlah biaya tetap per produsen ini dipengaruhi oleh perbedaan volume produksi, yang mengakibatkan perbedaan jumlah peralatan yang dimiliki.

Jumlah investasi dari 40 industri rumah tangga yaitu sebesar Rp171.000.000,00 dengan rata-rata modal sebesar Rp4.275.000,00. Dengan penyusutan rata-rata sebesar Rp14.250,00/bulan.

Peralatan yang digunakan masih sederhana dan dibeli pada awal pengusaha mulai menjalankan industri emping melinjo sehingga biaya penyusutan peralatan juga kecil. Sedangkan biaya bunga modal investasi berada pada urutan kedua, yaitu sebesar 5,2\%tahun. Nilai suku bunga diperoleh dari data Bank Indonesia yaitu sebesar 5,2\% pada bulan Oktober 2016, sebab penelitian ini dilakukan pada bulan tersebut. Jumlah bunga investasi dari 40 industri rumah tangga yaitu sebesar Rp7.410.000,00 dengan rata-rata bunga investasi sebesar Rp185.250,00. 


\section{Biaya variabel}

Biaya variabel adalah biaya yang digunakan dalam proses pembuatan emping melinjo yang besarnya berubah-ubah secara proporsional terhadap kuantitas output yang dihasilkan. Biaya-biaya yang termasuk dalam biaya variabel industri emping melinjo di Desa Cilowong Kec Taktakan adalah biaya bahan baku, biaya bahan bakar, pasir paenggoreng, biaya pengemasan, biaya transportasi dan biaya tenaga kerja yang dinyatakan dalam satuan rupiah.

Biaya bahan baku yaitu sebesar Rp 7.500 per kg. Besarnya kontribusi biaya bahan baku dikarenakan bahan baku harus dibeli melalui pedagang pengumpul. Selain itu harga bahan baku biji melinjo berfluktuasi yaitu berkisar antara $\mathrm{Rp}$ 7.000,00-8.500,00. Harga bahan baku emping melinjo yang berupa biji melinjo rata-rata sebesar Rp 7.500 per $\mathrm{kg}$.

Biaya bahan penolong yang dikeluarkan oleh pengusaha emping melinjo yaitu sebesar Rp 500,00 per kg. Bahan penolong yang digunakan dalam proses produksi emping melinjo adalah pasir. Satu kg pasir itu dapat dipakai untuk menyangrai $8 \mathrm{~kg}$ sampai $12 \mathrm{~kg}$ biji melinjo.

Dengan dilengkapi pasir, maka biji-biji melinjo yang disangrai akan dapat masak secara merata karena pasir sifatnya cepat menerima panas dari tungku api dan dengan mencampurkan biji-biji melinjo dengan pasir yang panas sambil dibolak-balik, maka kemasakan biji melinjo dapat merata.

Biaya tenaga kerja yang dikeluarkan oleh pengusaha emping melinjo yaitu sebesar Rp 4.000,00/kg. Jadi besar kecilnya upah tergantung dari jumlah produksinya. Tenaga kerja industri emping melinjo sebagian besar berasal dari tenaga kerja keluarga. Sebenarnya tenaga kerja keluarga dalam kenyataannya tidak diberi upah, namun konsep yang digunakan adalah keuntungan sehingga dalam perhitungan tetap dimasukkan.

Biaya bahan bakar arang yang dikeluarkan oleh pengusaha emping melinjo dengan harga Rp 3.000,00 per kg sedangkan jumlah fisik kayu bakar seharga Rp5.000,00 per ikat. Dalam proses produksi emping melinjo menggunakan tungku api sedangkan kebutuhan bahan bakar tergantung dari jumlah biji melinjo yang diolah.

Biaya pengemasan yang dikeluarkan oleh pengusaha emping melinjo di Desa Cilowong Kec Tatakan sebesar Rp100,00 per/lembar. Pengusaha emping melinjo membeli plastik dalam hitungan per biji untuk kemasan 0,5 dan $1 \mathrm{~kg}$ emping melinjo.

Penjualan emping melinjo dilakukan dengan cara dijual sendiri di pasar maupun konsumen yang memesan langsung dan atau melalui pedagang perantara. Emping melinjo yang dijual dalam skala besar biasanya dijual kepada pedagang perantara untuk menghemat biaya transportasi. Rata-rata biaya transportasi yang dikeluarkan oleh pengusaha emping melinjo selama satu bulan adalah sebesar Rp2,565.000,00/pengusaha. Besar kecilnya biaya transportasi dipengaruhi oleh 
jarak daerah pemasaran. Semakin jauh jarak daerah pemasaran, semakin besar biaya yang dikeluarkan. Biasanya pemasaran dilakukan setiap hari karena pengusaha memproduksi emping melinjo setiap hari.

\section{Biaya Total}

Biaya total adalah hasil dari penjumlahan seluruh biaya tetap dan biaya variabel yang dikeluarkan selama proses produksi. Rata-rata biaya total yang dikeluarkan pengusaha emping melinjo di Desa Cilowong Kec Taktakan selama satu bulan adalah sebesar Rp40.085.250,00. Biaya terbesar yang dikeluarkan dalam industri emping melinjo berasal dari biaya variabel "bahan baku emping melinjo yaitu sebesar Rp19.237.500,00.

Komposisi biaya variabel lebih banyak dibandingkan dengan komposisi biaya tetap sehingga biaya variabel yang dikeluarkan lebih besar. Selain itu juga disebabkan karena tingginya harga bahan baku untuk proses produksi emping melinjo.

\section{Penerimaan dan Keuntungan}

Penerimaan pengusaha emping melinjo merupakan perkalian antara total produk yang terjual dengan harga per $\mathrm{kg}$. Emping melinjo yang terjual oleh produsen selama satu bulan rata-rata sebesar $8.100 \mathrm{Kg}$ dengan harga tiap $\mathrm{Kg} \mathrm{Rp}$ 20.000,00. Dari jumlah emping melinjo yang terjual dan harga, maka dapat dihasilkan penerimaan. Besarnya penerimaan kotor yang diperoleh dari industri emping melinjo selama satu bulan rata-rata adalah sebesar Rp51.300.000,00. Keuntungan yang diperoleh dari industri emping melinjo merupakan selisih antara penerimaan dengan biaya total dengan rata-rata sebesar Rp11.214.750,00.

Dengan demikian, keuntungan rata-rata yang diperoleh setiap pengusaha emping melinjo selama satu bulan yaitu Oktober 2016 dengan rata-rata 9 karyawan adalah sebesar Rp 11.214.750,00.

Keuntungan yang diterima oleh pengusaha emping melinjo dipengaruhi oleh perbedaan jumlah emping melinjo yang dijual dan biaya yang dikeluarkan. Walaupun ada produsen emping melinjo yang hanya mendapat keuntungan kecil tapi usaha pembuatan emping melinjo ini tetap dilakukan oleh produsen. Hal ini disebabkan karena pada kondisi nyata banyak biaya yang tidak riil dikeluarkan oleh produsen, seperti bunga modal investasi dan upah tenaga kerja keluarga. Selain itu produsen juga merasa bahwa hasil dari usaha pembuatan emping melinjo telah mampu menambah penghasilan.

\section{Profitabilitas}

Berdasarkan keuntungan yang diperoleh, dapat diketahui profitabilitas atau tingkat keuntungan dari industri emping melinjo. Profitabilitas merupakan hasil bagi antara keuntungan usaha dengan biaya total yang dinyatakan dalam persen. 
Profitabilitas atau tingkat keuntungan dari industri emping melinjo skala rumah tangga di Desa Cilowong Kec Tatakan pada bulan Oktober 2016 adalah sebesar 21,86\%. Hal ini berarti setiap modal sebesar Rp 100,00 yang diinvestasikan akan diperoleh keuntungan Rp21,86. Misalnya saja, awalnya pengusaha emping melinjo mengeluarkan modal sebesar Rp 100.000,00 maka pengusaha akan memperoleh keuntungan sebesar $\mathrm{Rp} 21.860,00$. Industri emping melinjo ini termasuk dalam kriteria menguntungkan, karena memiliki nilai profitabilitas lebih dari nol. Profitabilitas ini merupakan hasil bagi antara keuntungan usaha dengan biaya total.

\section{Efisiensi}

Efisiensi usaha dapat dihitung dengan menggunakan R/C rasio, yaitu perbandingan antara penerimaan dan biaya yang dikeluarkan. Efisiensi industri emping melinjo skala rumah tangga di Desa Cilowong Kec Tatakan pada bulan Oktober 2016 sebesar 0,27. Hal ini berarti bahwa industri emping melinjo yang telah dijalankan belum efisien yang ditunjukkan dengan nilai $\mathrm{R} / \mathrm{C}$ rasio kurang dari satu. $\mathrm{R} / \mathrm{C}$ rasio ini menunjukkan pendapatan kotor yang diterima untuk setiap rupiah yang dikeluarkan untuk memproduksi. Nilai $\mathrm{R} / \mathrm{C}$ rasio 0,27 berarti bahwa setiap Rp 1,00 biaya yang dikeluarkan dalam suatu awal kegiatan usaha memberikan penerimaan sebesar 0,27 kali dari biaya yang telah dikeluarkan.

Sebagai contohnya, dalam awal kegiatan pengusaha emping melinjo mengeluarkan biaya $\mathrm{Rp} 100.000,00$ maka pengusaha akan memperoleh penerimaan sebesar $\mathrm{Rp}$ 27.000,00. Semakin besar R/C rasio maka akan semakin besar pula penerimaan yang akan diperoleh pengusaha. Nilai R/C rasio industri emping melinjo skala rumah tangga di Desa Cilowong Kec Taktakan belum efisien. Meski demikian, pengusaha emping melinjo sudah menggunakan faktor produksi dengan baik, yaitu menggunakan biji melinjo yang berkualitas tinggi sehingga diperoleh rendemen yang lebih besar. Rendemen yang tinggi akan mempengaruhi produk emping melinjo yang dihasilkan yaitu lebih banyak dan akhirnya penerimaan meningkat.

Semakin tinggi penerimaan yang diperoleh dan semakin rendah biaya total yang dikeluarkan maka efisiensi dari usaha juga akan semakin besar. Pengusaha emping melinjo tersebut masih tetap bisa berproduksi sampai sekarang walaupun harga bahan baku yang relatif tinggi karena pengusaha memiliki strategi dalam usahanya, yaitu apabila harga bahan baku mengalami kenaikan maka pengusaha berupaya untuk untuk memproduksi dalam kapasitas yang tetap, tetapi dengan mengurangi ukuran atau volume emping melinjo yang dihasilkan sehingga jumlah emping melinjo yang dihasilkan bertambah, dan penerimaan yang diterima dapat untuk menutup biaya bahan baku yang juga meningkat.

Hasil wawancara penelitian dengan pengusaha/pengrajinindustri kecil dan menengahemping, ditemukan bahwa pembinaan yang pernah diterima dari 
pemerintah adalah bantuan modal untuk pengadaan bahan baku buah melinjo tua oleh Dinas Kabupaten pada tahun 2010. Permasalahan yang dihadapi perajin industri kecil dan menengah emping Desa Cilowong Kecamatan Taktakan, Kota Serang, Provinsi Banten yang juga merupakan keluhan masyarakat setempat adalah: Prasarana jalan rusak berat, sehingga menghambat transportasi hasil ke pasar. Harga pokok penjualan meningkat akibat kenaikan harga BBM (Bahan Bakar Minyak) yang dengan sendirinya meningkatkan biaya transportasi hasil sehingga dikhawatirkan akan menurunkan angka penjualan emping. Harga jual hasil produksi emping ditentukan oleh pedagang, terutama di masa panen emping, harga menjadi sangat rendah.

Himbauan responden untuk pengembangan sentra adalah perbaikan sarana jalan agar pengeluaran biaya transportasi hasil ke pasar/kota tidak terlalu banyak mengurangi keuntungan mereka dari hasil penjualan yang diperoleh.

\section{Pembahasan}

Industrialisasi pertanian dikenal dengan nama agroindustri, dimana agroindustri dapat menjadi salah satu pilihan strategis dalam menghadapi masalah dalam upaya peningkatan perekonomian masyarakat di pedesaan serta mampu menciptakan kesempatan kerja bagi masyarakat yang hidup di pedesaan. Sektor industri pertanian merupakan suatu sistem pengelolaan secara terpadu antara sektor pertanian dengan sektor industri guna mendapatkan nilai tambah dari hasil pertanian. Agroindustri merupakan usaha untuk meningkatkan efisiensi sektor pertanian hingga menjadi kegiatan yang sangat produktif melalui proses modernisasi pertanian. Modernisasi di sektor industri dalam skala nasional dapat meningkatkan penerimaan nilai tambah sehingga pendapatan ekspor akan lebih besar (Wahyuni, Erin, dan Nurhadi, 2013).

Membaca uraian di atas, pada dasarnya hasil penelitian ini juga mendukung temuan tersebut. Industri emping melinjo di kelurahan Cilowong, Kecamatan Taktakan Kota Serang dapat menjadi salah satu pilihan strategis dalam menghadapi masalah dalam upaya peningkatan perekonomian masyarakat di pedesaan serta mampu menciptakan kesempatan kerja bagi masyarakat yang hidup di pedesaan. Jumlah tenaga kerja yang diserap oleh 40 perusahaan industri emping melinjo rata-rata sebanyak 9 orang. Sektor industri ini juga mampu member nilai tambah dari hasil pertanian.

Sebagaimana dikatakan oleh Wirakartakusumah (1997), keberadaan industri pangan di Indonesia dapat menyerap tenaga kerja dalam jumlah yang cukup banyak serta mampu mendorong berdirinya industri penunjang seperti industri pengolahan makanan dan industri kemasan yaitu suatu industri yang memproduksi kemasan suatu produk seperti kemasan berbahan baku plastik, kertas, kaca, dan lainnya.

Soekartawi (1993) juga menjelaskan bahwa agroindustri diharapkan dapat memainkan peranan penting dalam kegiatan pembangunan daerah, baik dalam 
pemerataan pembangunan, pertumbuhan ekonomi, maupun stabilitas nasional. Keberadaan agroindustri di pedesaan diharapkan dapat meningkatkan permintaan terhadap komoditas pertanian, karena sektor agroindustri sangat berperan dalam mengubah produk pertanian menjadi barang yang lebih bermanfaat.

Hasil penelitian di Cilowong Kecamatan Taktakan ini juga mendukung hasil penelitian tentang Usaha Agroindustri Emping Melinjo yang dilakukan Cholifah (2003) di Kabupaten Kulonprogo menunjukkan bahwa agroindustri emping melinjo sudah mampu memberikan keuntungan sebesar Rp. 388.145,06. Selain itu usaha agroindustri emping melinjo juga sudah efisien, hal ini ditunjukkan dengan nilai R/C Rasio sebesar 1,26. Walaupun menguntungkan, tetapi usaha agroindustri emping melinjo juga mempunyai kemungkinan rugi, hal ini ditunjukkan dengan nilai $\mathrm{CV}$ yang lebih besar dari 0,5 dan nilai batas bawah keuntungan yang negatif, yaitu (-) 158.717,03.

Hasil penelitian ini juga sejalan dengan temuan penelitian yang dilakukan oleh Usnun (2004) yang menunjukkan bahwa penerimaan yang diperoleh produsen home industri selama bulan Oktober 2003 sebesar Rp 2.411.931,00 dengan biaya total rata-ratanya sebesar Rp 2.095.115,00 sehingga keuntungan rata- rata yang diperoleh selama bulan Oktober $2003 \mathrm{Rp} 316.816,00$. Profitabilitas dari usaha ini sebesar 15,2\%. Koefisien Variasi dari usaha ini adalah 0,65, dengan simpangan baku Rp 204.258,00 dan batas bawah keuntungan sebesar minus Rp 91.700,00. Usaha ini sudah efisien dengan nilai R/C sebesar 1,15 yang berarti setiap 1 Rupiah biaya yang dikeluarkan akan didapatkan penerimaan 1,15 kali dari biaya yang dikeluarkan.

Hasil penelitian ini juga sejalan dengan temuan Mahadewi (2002) tentang Usaha Agroindustri di Kecamatan Adimulyo Kabupaten Kebumen, diketahui bahwa biaya rata-rata yang dikeluarkan dalam satu kali produksi sebesar Rp 280.674,71 dengan rata-rata produksi sebesar 104.31 kilogram. Penerimaan yang diperoleh dalam satu kali produksi sebesar Rp 305.937,50 sehingga diperoleh keuntungan sebesar Rp 25.262,79 dengan profitabilitas sebesar $9 \%$. Koefisien variasi dari usaha ini sebesar 1,52 dengan batas bawah keuntungan sebesar minus Rp 51.547,51. Walaupun nilai risiko dari usaha ini cukup besar, namun usaha agroindustri ini di Kecamatan Adimulyo ini sudah efisien, terbukti dengan nilai $\mathrm{R} / \mathrm{C}$ nya sebesar 1,09 .

Hasil penelitian ini juga sejalan dengan penelitian yang dilakukan Indri (2005) dengan judul Analisis Usaha Industri di Kota Surakarta diketahui bahwa biaya total rata-rata yang dikeluarkan untuk industri di Kota Surakarta dalam satu bulan sebesar Rp 11.306.025,00. Sedangkan penerimaan rata-rata yang diperoleh pengusaha selama sebulan sebesar Rp 14.616.452,00 sehingga keuntungan ratarata yang diperoleh produsen selama satu bulan adalah Rp3.310.427,00. Profitabilitas dari usaha ini di Kota Surakarta adalah 29,3\% yang berarti usaha yang dilakukan menguntungkan. Besarnya risiko yang mungkin terjadi Rp 
2.157.521,00 dan batas bawah keuntungan sebesar minus Rp 1.004.615,00 yang berarti produsen harus berani menanggung kerugian sebesar Rp 1.004.615,00. Sedangkan efisiensi usahanya adalah 1,293. Hal ini menunjukkan bahwa usaha di Kota Surakarta sudah efisien.

Sentra emping di Cilowong Kecamatan Taktakan Provinsi Banten merupakan sentra pada lokasi yang relative tidak jauh dari ibukota Negara Jakarta, yaitu sekitar $90 \mathrm{~km}$, yang merupakan pasar potensial bagi sentra sentra industri kecil dan menengah di sekitarnya, untuk itu selayaknya perumusan kebijakan pengembangan yang tepat melalui pendataan tentang keberadaan dan potensi sentra tersebut perlu diperbaharui.

Hasil penelitian ini juga pendukung temuan Utami, Suyatno, dan Imelda (2014:1) menjelaskan bahwa (1) rata-rata keuntungan usaha industri emping melinjo skala rumah tangga di Kelurahan Sungai Jawi Kecamatan Pontianak Kota yang dihasilkan responden selama satu bulan yaitu sebesar Rp.1.179.923/Bln. (2) Variabel yang mempengaruhi produksi emping melinjo adalah jumlah bahan baku. Sedangkan variabel jumlah tenaga kerja tidak berpengaruh nyata terhadap produksi emping melinjo.

Berdasarkan hasil penelitan tersebut dapat diketahui bahwa usaha agroindustri industri emping melinjo dapat menghasilkan keuntungan. Besarnya keuntungan dipengaruhi oleh besarnya penerimaan dan besarnya biaya yang dikeluarkan. Selain itu besarnya penerimaan dan besarnya biaya yang dikeluarkan akan menunjukkan besarnya tingkat efisiensi dari pengelolaan usaha tersebut. Meskipun usaha tersebut menghasilkan keuntungan akan tetapi usaha tersebut tetap mempunyai kemungkinan adanya kerugian.

Hal-hal yang dapat dilakukan oleh pengrajin agar lebih efisien antara lain: Pertama, dari sisi bahan baku, para produsen dapat menggunakan bahan baku lokal sehingga tidak perlu mendatangkan dari daerah lain. Dengan demikian, harga bahan baku menjadi lebih murah karena tidak ada biaya trasportasi.

Kedua, dari sisi produksi, pra produsen dapat menjemur terlebih dahulu bahan bakunya sehingga mempercepat proses produksi. Denan demikan dapat menghemat penggunakan bahan bakar baik kayu bakar maupun bahan bakar gas.

Ketiga, dari sisi pengemasan, para pengrajin dapat menggunakan alat kemas vacum udara dengan cara pengadaan bersama atau patungan, sehingga akan memperlama umur produk di pasaran, karena tidak lekas kedaluwarsa.

\section{KESIMPULAN}

Berdasarkan hasil penelitian dan analisis yang telah dilakukan, dapat diperoleh kesimpulan jumlah investasi dari 40 industri rumah tangga yaitu sebesar Rp171.000.000,00 dengan rata-rata modal sebesar Rp4.275.000,00. Rata-rata biaya total yang dikeluarkan pengusaha emping melinjo di Desa Cilowong Kec Taktakan selama satu bulan adalah sebesar Rp40.085.250,00. Biaya terbesar yang dikeluarkan dalam industri emping melinjo berasal dari biaya variabel "bahan 
baku emping melinjo yaitu sebesar Rp19.237.500,00. Emping melinjo yang terjual oleh produsen selama satu bulan rata-rata sebesar $8.100 \mathrm{Kg}$ dengan harga tiap $\mathrm{Kg} \operatorname{Rp} 20.000,00$. Keuntungan yang diperoleh dari industri emping melinjo merupakan selisih antara penerimaan dengan biaya total dengan rata-rata sebesar Rp11.214.750,00. Hal ini berarti setiap modal sebesar Rp100,00 yang diinvestasikan akan diperoleh keuntungan Rp21,86. Efisiensi industri emping melinjo skala rumah tangga di Desa Cilowong Kec Tatakan pada bulan Oktober 2016 sebesar 0,27. Hal ini berarti bahwa industri emping melinjo yang telah dijalankan belum efisien yang ditunjukkan dengan nilai $\mathrm{R} / \mathrm{C}$ rasio kurang dari satu. R/C rasio ini menunjukkan pendapatan kotor yang diterima untuk setiap rupiah yang dikeluarkan untuk memproduksi. Nilai $\mathrm{R} / \mathrm{C}$ rasio 0,27 berarti bahwa setiap Rp 1,00 biaya yang dikeluarkan dalam suatu awal kegiatan usaha memberikan penerimaan sebesar 0,27 kali dari biaya yang telah dikeluarkan.

Rekomendasi yang diberikan kepada para pengrajin emping melinjo hendaknya memperhatikan berbagai peghematan yang bisa dilakukan sehingg akan mampu meningkatkan keuntungan tanpa harus menaikkan harga. Langkah efisiensi yang dapat dilakukan antara lain: (1) memaksimalkan bahan baku produk lokal, (2) penggunaan metode penjemuran sehingga mampu mengurangi biaya bahan bakar saat pengolahan, dan (3) penggunaan vacum udara dalam proses pengemasan agar barang produksi yang dihasilkan bisa lebih tahan lama.

Keterbatasan PenelitianPenelitiaan ini menggunakan metode studi kasus dengan sampel terbatas. Oleh karena itu, kepada para peneliti berikutnya hendaknya dapat meneliti konsep sejenis dengan cakupan wilayah yang lebih luas dan sampel yang lebih banyak.

\section{REFERENSI}

Arifia, Dina. 2017. Industri Kreatif Rumah Tangga (Studio Proses - Analisis) (online) http://www.academia.edu/8264216/Industri_Kreatif_Rumah_Tangga_ diakses tanggal 4 Oktober 2017

Asri, Ika Wahyu Yuni. 2010. Analisis Usaha Industri Emping Melinjo Skala Rumah Tangga Di Kabupaten Magetan Skripsi. Surakarta: fakultas pertanian Universitas Sebelas Maret. (Online) http://eprints.uns.ac.id/204/1/170492411201011351.pdf diakses tanggal 3 Oktober 2017

Cholifah, T. 2003. Analisis Usaha Agroindustri Emping Melinjo di Kabupaten Kulonprogo. Skripsi. Fakultas Pertanian UNS. Surakarta.

Devvy, Ummu. $2017 . \quad$ Konsep Biaya. (online) https://id.scribd.com/document/50947163/Konsep-Biaya-Relevan diakses tanggal 13 Oktober 2017 
Dryana, Ann. 2017. Akuntansi Biaya - Konsep Biaya (online) https://id.scribd.com/doc/72660453/Akuntansi-Biaya-Konsep-Biaya-pdf diakses tanggal 12 Oktober 2017

Indri, C. 2005. Analisis Usaha Industri Intip di Kota Surakarta. Skripsi Fakultas Pertanian. UNS. Surakarta.

Iqbal Muhammad. 2017. Konsep Biaya (Teori Akuntansi). (Online). http://www.academia.edu/25709758/Konsep_Biaya_Teori_Akuntansi_ diakses tanggal 8 Oktober 2017

Kemenperin (2017) Kemenperin: Sektor Manufaktur Serap 16,3 Juta Tenaga Kerja (on-line) http://www.kemenperin.go.id/artikel/17020/SektorManufaktur-Serap-16,3-Juta-Tenaga-Kerja. Diakses tanggal 3 Oktober 2017-10-30

Mahadewi, H. 2002. Analisis Usaha Agroindustri Lanting Di Kecamatan Adimulyo Kabupaten Kebumen. Skripsi FP UNS. Surakarta.

Samuelson, P. A dan W. D. Nordhaus 2003. Ilmu MikroEekonomi. Jakarta: PT. Media

Usnun, M. K. I. 2004. Analisis Usaha Pembuatan Krupuk Rendeng Puyur di Kecamatan Tuntang Kabupaten Semarang. Skripsi FP UNS. Surakarta.

Utami, Ika Puji; Adi Suyatno, Imelda Imelda. Analisis Keuntungan Usaha Industri Emping Melinjo Skala Rumah Tangga Di Kelurahan Sungai Jawi Kecamatan Pontianak Kota. Jurnal Sains Mahasiswa Pertanian Vol IV No 2. Online: http://jurnal.untan.ac.id/index.php/jspp

Wahyuni, Erin dan Nurhadi. 2013. Strategi Pengembangan Industri Emping Melinjo Di Desa Wirokerten Kecamatan Banguntapan Kabupaten Bantul. Jurnal Geo Educasia Tahun II, Vol IV, Tahun 2013. Online: http://www. http://journal.student.uny.ac.id/jurnal (Diakses tgl 18 Januari 2016) 